\title{
EFFECT OF THE KIND OF HABITAT ON FLOWERING OF HIEROCHLOË REPENS (HOST) SIMONKAI
}

\author{
Krzysztof Gęsiński \\ Department of Botany and Ecology, University of Technology and Life Science in Bydgoszcz, Prof. S. Kaliskiego 7, \\ 85-796 Bydgoszcz, Poland \\ e-mail: gesinski@utp.edu.pl
}

Received: 15.09 .2007

\section{S u m m a r y}

Studies on flowering of Hierochloë repens were performed over the years 2005-2007 in five habitats located in Bydgoszcz. The first habitat is a degenerated fresh ryegrass meadow (Arrhenatheretum elatioris). Another one is a degenerated form of initial xerothermic swards (Tunico-Poetum compressae). The third habitat in which the occurrence of Hierochloë repens was found and flowering was analyzed is sandy sward (Koelerio-Corynephoretea). Yet another habitat is ruderal in character and it was located on the side of the road (Convolvulo-Brometum iner$m i s)$. The last one is a fertile and moist habitat of elm-ash marshy meadow being gramineous herb fringe communities in character. The evaluation was based on the following analyses: morphological characters of inflorescences (length of inflorescence, stem length, number of inflorescence branches and number of spikelets), stem and inflorescence weight and reproduction effort as well as the share of generative individuals in the population and the number of generative individuals per $\mathrm{m}^{2}$. Differences were found in the structure of Hierochloe repens inflorescence in the habitats analyzed. The biggest inflorescence, in terms of all the characters analyzed, was found in fertile elm-ash marshy meadow, and the smallest in poor xerothermic sward. The highest generative reproduction potential of Hierochloë repens was found in the ruderal habitats. They are the basic potential source of generative diaspora production, which can affect the spreading of this species in Poland.

Key words: Hierochloë repens, flowering, habitat

\section{INTRODUCTION}

Hierochloë repens (Host) P.B. or (Host) Simonkai - Flora Europea (1964-1980) is a species which was differentiated from Hierochloë odorata L. and recently found in Poland. Despite a considerable similarity to Hierochloë odorata and Hierochloë australis, it shows different characteristics. It does not have hirsute, in the base of the petiole of the spikelet, and aristate glumelle of staminate floret, like Hierochloë australis. Leaves are not hirsute on the top like in Hierochloë odorata. However it has an egg-shaped thick panicle of a much greater number of spikelets than the previous species (even up to 300), and glumelle of bisexual flower is adjacently hirsute. The first stand of Hierochloë repens was located in the central part of Bydgoszcz in 1989 (G ę s i ń s k i, 2003). In successive years, new stands were found not only in the city but also in the Kujawsko-Pomorskie Province (Rutkowski, 1997a,b, 1998), and also recently in the south of Poland (Rostańs ki at al. 2005). Hierochloe repens is a xeromezophyte adapted to light sandy soils. It grows in sandy swards, pine forests and on their edges. It also grows in dry meadows, steppe slopes, sands and shrubbery thickets. It is found in gardens close to fences and in the vicinity of lawns (G ę s i ń s k i, 2003). F e d o r ov (1976) locates Hierochloë repens in dry meadows, sands, forest meadows, in thin forests and meadow steppes, at the roads, sometimes on crop plantations. It also accounts for an insignificant share of psammophilic typical needlegrass steppes, while on post-steppe fallow it forms a temporary plant community (Znaki Ukrainu, 1977). A wide ecological spectrum of occurrence of the species in Poland, the tendency to enter new habitats demonstrates an expansive character of the species. It was observed, however, that Hierochloë repens shows limited flowering in some habitats which is not found in others. Assuming that flowering, generative reproduction is the basis of the species spreading, relevant research was undertaken.

The working hypothesis assumes that based on the evaluation of flowering of Hierochloë repens it will be possible to define basic sources of production of diasporas of this species in Poland. The aim of this paper is 
to define differences in flowering depending on the kind of habitat and hence the potential of Hierochloë repens spreading from specific kinds of habitats.

\section{MATERIALS AND METHODS}

Studies on flowering of Hierochloë repens were performed over the years 2005-2007 in five habitats located in Bydgoszcz. The first habitat (A) is a degenerated fresh ryegrass meadow (Arrhenatheretum elatioris). Another one (B) is a degenerated form of initial xerothermic swards (Tunico-Poetum compressae). The third habitat (C) in which the occurrence of Hierochloë repens was found and flowering was analyzed is sandy sward (Koelerio-Corynephoretea). Yet another habitat (D) is ruderal in character and it was located on the side of the road ( $\mathrm{Co}$ nvolvulo-Brometum inermis). The last one (E) is a fertile and moist habitat of elm-ash marshy meadow being gramineous herb fringe communities in character.

The evaluation of Hierochloë repens flowering in selected habitats was based on the following analyses: morphological characters of inflorescences (length of inflorescence, stem length, number of inflorescence branches and number of spikelets), stem and inflorescence weight and reproduction effort as well as the share of generative individuals in the population (it was assumed that an individual was a single overground stem) and the number of generative individuals per $\mathrm{m}^{2}$. The analysis of characters of the morphological structure was made based on measurements of 30 inflorescences from each habitat. The results of the measurements were subjected to basic analyses, the arithmetic mean and LSD were determined. To evaluate the similarity of the reproduction potential between populations in the habitats analyzed, a comparison was made based on yearly means with the cluster analy- sis, using the complete linkage method with the use of the Euclidean distance. To develop the present paper, EXCEL, STATISTICA statistical package and Microsoft Word processor were used.

\section{RESULTS}

Significant differences were demonstrated in morphological characters of Hierochloë repens inflorescence between the habitats analyzed (Table 1). The greatest length of the inflorescence was identified in habitats C, E and they were significantly longer than the inflorescences in the other habitats, while the stem length varied more. The shortest one was found in habitat $\mathrm{C}$, followed by $\mathrm{B}$ and $\mathrm{A}$, the significantly longest was found in stands $\mathrm{D}$ and $\mathrm{E}$. The number of spikelets per inflorescence in the treatments analyzed correlated with the inflorescence length, except for inflorescences Hierochloë repens in stand A where despite a short inflorescence, the number of spikelets was greater, similarly as the number of branches. However, during a comparison of the weight of inflorescence and stem of Hierochlö repens across the habitats it was found that a significantly higher value was identified for the organs in E stand, unlike in the others.

The reproduction effort of Hierochloë repens assumes relatively high values (from 41.8 to $58.2 \%$ ), irrespective of the kind of the habitat. However, there were also found significant differences in the values of the character studied across the treatments analyzed (Tab. 2). The greatest reproduction effort was found in the individuals in habitats $\mathrm{A}$ and $\mathrm{C}$ and it was significantly different than $\mathrm{B}, \mathrm{D}$ and $\mathrm{E}$.

To evaluate the reproduction potential of Hierochloë repens, the percentage of generative individuals in the population was also analyzed. It was demonstra-

Table 1

Values of the inflorescence characters of Hierochloë repens in the habitats analyzed.

\begin{tabular}{|c|c|c|c|c|c|c|}
\hline Habitat & $\begin{array}{c}\text { Inflorescence } \\
\text { length }(\mathrm{cm})\end{array}$ & $\begin{array}{c}\text { Stem length } \\
(\mathrm{cm})\end{array}$ & $\begin{array}{c}\text { Number of } \\
\text { spikelets }\end{array}$ & $\begin{array}{c}\text { Number of } \\
\text { branches }\end{array}$ & $\begin{array}{c}\text { Inflorescence } \\
\text { weight }(\mathrm{g})\end{array}$ & $\begin{array}{c}\text { Stem weight } \\
(\mathrm{g})\end{array}$ \\
\hline $\mathrm{A}$ & 6.68 & 38.9 & 113.3 & 19.2 & 0.096 & 0.181 \\
\hline $\mathrm{B}$ & 5.92 & 34.3 & 78.8 & 17.2 & 0.073 & 0.179 \\
\hline $\mathrm{C}$ & 7.27 & 31.0 & 110.2 & 19.1 & 0.095 & 0.170 \\
\hline $\mathrm{D}$ & 6.80 & 44.9 & 96.0 & 18.7 & 0.093 & 0.219 \\
\hline $\mathrm{E}$ & 7.80 & 45.0 & 114.3 & 19.2 & 0.121 & 0.283 \\
\hline Mean & 6.89 & 38.8 & 102.5 & 18.7 & 0.096 & 0.207 \\
\hline LSD \\
$\mathrm{a}=0,05$ & 0.881 & 3.185 & 19.52 & 1.422 & 0.022 & 0.056 \\
\hline
\end{tabular}


Table 2

Characters defining potential of reproduction of Hierochloë repens in the habitats analyzed.

\begin{tabular}{|c|c|c|c|}
\hline Habitat & $\begin{array}{c}\text { Reproduction effort } \\
(\%)\end{array}$ & $\begin{array}{c}\text { Share of flowering } \\
\text { individuals (\%) }\end{array}$ & $\begin{array}{c}\text { Density of generative } \\
\text { individuals per } \mathrm{m}^{2}\end{array}$ \\
\hline A & 55.2 & 2.24 & 4.05 \\
\hline B & 41.8 & 0.649 & 0.37 \\
\hline C & 58.2 & 2.46 & 3.4 \\
\hline D & 42.9 & 48.34 & 100 \\
\hline E & 42.9 & 0.075 & 0.37 \\
\hline Mean & 48.2 & 10.74 & 21.64 \\
\hline
\end{tabular}

ted that in habitat $\mathrm{D}$ the share of these individuals was many-fold higher than in the others and accounted for $48 \%$, while populations in the other habitats (Tab. 2) demonstrated a low share of flowering individuals. However, also here a difference was found across the habitat groups: the first were habitats $\mathrm{A}$ and $\mathrm{C}$ where the share of flowering individuals was about $2.5 \%$, and the next group were habitats $\mathrm{B}$ and $\mathrm{E}$ where it was $0.6 \%$ and less. Similar relations were also found based on the density of generative individuals.

To verify the significance of the differences in the potential of generative reproduction Hierochloe repens in the habitats analyzed, the cluster analysis was made and used to identify no similarity between habitat $\mathrm{D}$ of the highest generative reproduction potential and the others (Fig. 1), of which cluster 3 was differentiated in which there were found habitats $\mathrm{A}$ and $\mathrm{C}$ of low generative reproduction potential and cluster 2 (cluster B and E) in which the reproduction potential was limited.

\section{DISCUSSION}

When evaluating the flowering of Hierochloë repens in selected kinds of habitats, one may state that the species shows preferences of specific conditions. Irrespective of them, however, it flowers in early spring, from mid April to mid May. Znak i Ukra in u (1977) considers it to be a xeromezophyte. Even though it comes from steppe areas of Ukraine (P r o k t s d i n , 1987)

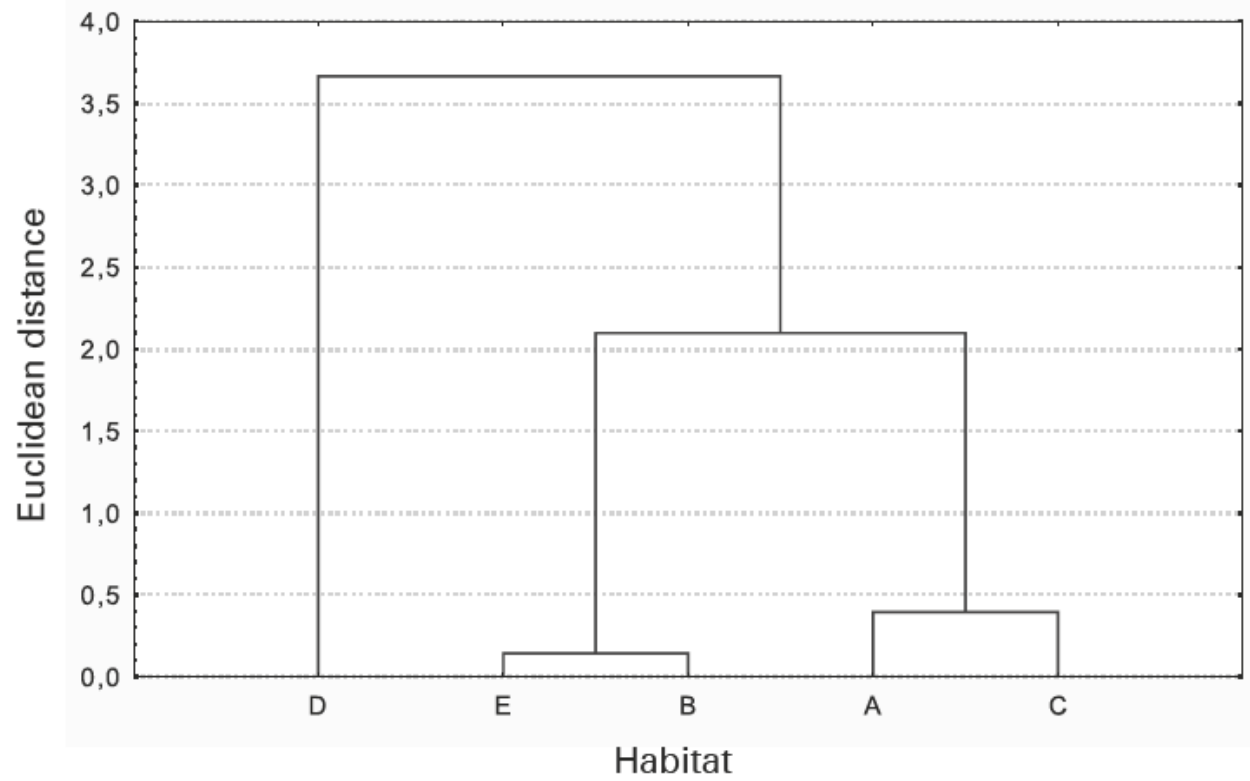

Fig. 1. Similarity of potential of generative reproduction of Hierochloë repens in the habitats analyzed. 
and shows adaptation to light and sandy soils (F 1 or a Eur o p e a, 1964-1980), its mesophilic character also allows it to enter even more fertile habitats of heavy soils and even heavily moist, like elm-ash marshy meadow. It demonstrates unique ecological plasticity in adapting to these conditions not only in terms of morphology, but also generative reproduction.

The number of florets in the inflorescence is usually connected with the total plant habit ( $\mathrm{C} \mathrm{z}$ a r $\mathrm{n} \mathrm{e} \mathrm{ck} \mathrm{a}$, 1995). In the case of Hierochloë repens, the number of florets, and as a result, the weight of the inflorescence, is determined by the number of branches of panicle and so the highest number of florets was found in habitat $E$ of elm-ash marshy meadow, and the lowest in the xerothermic sward, while the number of florets in this species is closely connected with the number of spikelets. Each spikelet consists of three florets, one bisexual floret and two staminate florets.

When evaluating the reproduction potential of Hierochloë repens, one may state clear differences and similarity of this character between the populations of specific habitats. The conditions of fresh ryegrass meadow show a low (a few percent) share of flowering individuals and their density, similarly as the habitat of sandy sward, while the habitat of xerothermic sward, despite essential differences in the moisture, fertility, as compared with the habitat of elm-ash marshy meadow, also shows similar and even more limited generative reproduction potential, and in the shade conditions under the canopy of the tree, no generative individuals at all and the limitation of reproduction only to vegetative reproduction. Probably the limited insolation under these conditions stimulates such a reaction, which is confirmed by the report by Grammatikopoulos et al. (2001), while the highest generative reproduction potential was found in ruderal habitats of ConvolvuloBrometum inermis which can be considered the basic source of the species expansion. Already the presence of this new species in Poland in ruderal habitats, treated as tracks of species spreading, shows its dynamic character, while the fact that in these habitats it demonstrates the greatest generative reproduction potential, over 20 -fold higher than in the others, clearly shows its preferences and possibly the main source of the species spreading in Poland.

\section{CONCLUSIONS}

1. Differences were found in the structure of Hierochloë repens inflorescence in the habitats analyzed.

2 . The biggest inflorescence, in terms of all the characters analyzed, was found in fertile elm-ash marshy meadow, and the smallest in poor xerothermic sward.
3. The highest generative reproduction potential of Hierochloë repens was found in the ruderal habitat.

4. The basic potential source of generative diaspora production, which can affect the spreading of Hierochloë repens in Poland, are ruderal habitats at this stage.

\section{REFERENCES}

C z a r n e c k a B., 1995. Biologia i ekologia izolowanych populacji Senecio rivularis (Waldst. et Kit.) DC. i Senecio umbrosus Waldst.et Kit. / Biology and ecology of isolated populations of Senecio rivularis (Waldst. et Kit.) DC. and Senecio umbrosus Waldst.et Kit. Wyd. Univ. Mariae $\mathrm{Cu}-$ rie Skłodowska, Lublin.

F e d o r o v An. A., 1976. Poaceae URSS. Nauka. Sectio Leninopoli.: 352-353.

F 1 o r a E u r o p e a, 1964-1980, Eds. T.G. Tutin, V.H. Heywood, N.A. Burges, D.M. Moore, D.H. Valentine, S.M. Walters, D.A. Webb, Univ. Press, Cambridge.T V: 229.

G ę s i ń s k i K., 2003. Population of Hierochloë repens (Host) $P . B$. in the Bydgoszcz town. Flora miast. Leśny Park Kul. I Wyp., Kuj.-Pom. Centr. Edu. Ekol., PTB: 148-153.

Gram m a ti k o poul os G., Drillas P., K y p aris sias A., Pe trop oulou Y., M a n e tas Y., 2001. Reduction of ambient UV-B radiation does not affect growth but may change the flowering pattern of Rosmarinus officinalis L. Plant Ecol. 154: 119-122.

Proktsdin Ju. N., 1987: Opredelitel vysshikh rastenii Ukrainy. Nauchoba Dumka. Kiev.: 448.

R o s t a ń s k i A., W ą s o w i c z P., C z y b a M., 2005: New localities of Hierochloë odorata s. lato in the Silesian Upland (S Poland), Biology of grasses, edited by Ludwig Frey, Szafer Institute of Botany, Polish Academy of Sciences, Kraków.

R u t k o w s k i L., 1997a. Dokumentacja florystyczna i fitosocjologiczna projektowanego Chełmińsko-Nadwiślańskiego Parku Krajobrazowego. / Floristic and phytosociological documentation of the planned Chełmno-Vistula River Valley Landscape Park. Dla Woj. Biura Planowania Przestrzennego Gospodarstwa Pomocniczego "Torplan". ss. 22.

R u t k o w s k i L., 1997b. Roślinność kserotermiczna i lasy łęgowe Przyłubia. / Xerothermic vegetation and riparian forests of Przyłubie. Projekt Zespołu Przyrodniczo-Krajobrazowego. Dla Woj. Konserwatora Przyrody w Bydgoszczy. ss. 19.

R u t k o w s k i L., 1998. Projektowany rezerwat Zbocza Dybowskie i zespół przyrodniczo-krajobrazowy w leśnictwie Dybowo. / The planned Dybowo Slopes Reserve and a nature and landscape site in the Dybowo forest region. Na zamówienie Wydziału Ochrony Środowiska Urzędu Wojewódzkiego w Toruniu. ss. 29.

Znaki Ukrainu, 1977: Nauchoba Dumka. Kiev.: 236-239. 


\section{Wpływ rodzaju siedliska na kwitnienie Hierochloë repens (Host) Simonkai}

\section{Streszczenie}

Badania dotyczące kwitnienia Hierochloë repens przeprowadzono w latach 2005-2007 w pięciu siedliskach zlokalizowanych na terenie Bydgoszczy. Pierwsze siedlisko to zdegenerowana świeża łąka rajgrasowa (Arrhenatheretum elatioris). Kolejne to postać degeneracyjna inicjalnej murawy kserotermicznej (TunicoPoetum compressae). Trzecim siedliskiem, w którym stwierdzono występowanie Hierochloë repens i analizowano kwitnienie to murawa piaskowa (Koelerio-Corynephoretea). Następnym jest siedlisko o charakterze ruderalnym zlokalizowane na poboczu drogi (Convolvulo-Brometum inermis). Ostatnim jest żyzne i wilgot- ne siedlisko łęgu wiązowo-jesionowego o charakterze trawiastego ziołorośla. Ocenę oparto o analizy: cech morfologicznych kwiatostanów (długość kwiatostanu, długość łodygi, liczbę rozgałęzień kwiatostanu i liczbę kłosków), masę łodygi i kwiatostanu oraz wysiłek reprodukcyjny, a także udział osobników generatywnych w populacji i liczbe osobników generatywnych na $\mathrm{m}^{2}$. Stwierdzono różnice $\mathrm{w}$ budowie kwiatostanu Hierochloë repens $\mathrm{w}$ analizowanych siedliskach. Największy kwiatostan pod względem wszystkich analizowanych cech stwierdzono w żyznym łęgu wiązowo-jesionowym, a najmniejszy w ubogiej murawie kserotermicznej. Największe potencjalne możliwości reprodukcji generatywnej Hierochloë repens stwierdzono w siedliskach ruderalnych. Stanowią one podstawowe potencjalne miejsce produkcji diaspor generatywnych, co może mieć wpływ na rozprzestrzenianie się tego gatunku w Polsce. 
